\title{
Correction to: Understanding National Preferences in EU Consumer Policy: a Regime Approach
}

\section{H. Austgulen ${ }^{1}$}

Published online: 19 October 2020

(C) The Author(s) 2020

\section{Correction to: Journal of Consumer Policy https://doi.org/10.1007/s10603-020-09468-8}

The original article unfortunately contains cut-off Appendix A and missing Appendix B. The corrected Appendix A and B should be. 
Appendix A: Operationalisations of variables based on the "full questionnaire" in the open public consultation $(\mathrm{N}=152)$

\begin{tabular}{|c|c|c|c|c|c|c|}
\hline Categorisation & Variable & Question / Statement & $\begin{array}{l}\text { Variable } \\
\text { /Index code }\end{array}$ & $\begin{array}{l}\text { Variable / Index } \\
\text { name }\end{array}$ & KMO & $\begin{array}{l}\text { Cronba } \\
\text { ch's } \\
\text { Alpha }\end{array}$ \\
\hline \multirow{13}{*}{$\begin{array}{l}\text { Understanding } \\
\text { of problems }\end{array}$} & 3 & \multicolumn{3}{|c|}{$\begin{array}{l}\text { How important are the following problems for protecting the } \\
\text { rights of consumers? }\end{array}$} & .878 & \\
\hline & $3 \mathrm{a}$ & $\begin{array}{l}\text { Consumers don't know/ don't } \\
\text { understand their rights }\end{array}$ & \multirow[b]{2}{*}{ V3_f2 } & \multirow[b]{2}{*}{$\begin{array}{l}\text { Understanding } \\
\text { of consumer law }\end{array}$} & & \multirow[b]{2}{*}{.664} \\
\hline & $3 b$ & $\begin{array}{l}\text { Traders don't know/ don't } \\
\text { understand consumer protection } \\
\text { rules }\end{array}$ & & & & \\
\hline & $3 \mathrm{c}$ & $\begin{array}{l}\text { Traders don't comply } \\
\text { with consumer protection rules }\end{array}$ & v3_a & Uncategorised & & \\
\hline & $3 \mathrm{~d}$ & Consumer law is too complex & \multirow[b]{2}{*}{ V3_f3 } & \multirow[b]{2}{*}{$\begin{array}{l}\text { Complex } \\
\text { consumer law }\end{array}$} & & \multirow[b]{2}{*}{.420} \\
\hline & $3 \mathrm{e}$ & $\begin{array}{l}\text { There are significant differences } \\
\text { between national consumer } \\
\text { protection rules across EU countries }\end{array}$ & & & & \\
\hline & $3 \mathrm{f}$ & $\begin{array}{l}\text { National administrative authorities } \\
\text { lack legal powers to enforce } \\
\text { consumer rights }\end{array}$ & \multirow{7}{*}{ V3_f1 } & \multirow{7}{*}{$\begin{array}{l}\text { Inefficient } \\
\text { enforcement of } \\
\text { consumer law }\end{array}$} & & \multirow{7}{*}{.923} \\
\hline & $3 \mathrm{~g}$ & $\begin{array}{l}\text { National authorities responsible for } \\
\text { enforcing consumer rights are not } \\
\text { active enough }\end{array}$ & & & & \\
\hline & $3 \mathrm{~h}$ & $\begin{array}{l}\text { Court proceedings are complex / } \\
\text { long / costly }\end{array}$ & & & & \\
\hline & $3 \mathrm{i}$ & $\begin{array}{l}\text { Administrative enforcement } \\
\text { proceedings are complex / long / } \\
\text { costly }\end{array}$ & & & & \\
\hline & $3 \mathrm{j}$ & $\begin{array}{l}\text { Injunctions proceedings are } \\
\text { complex / long }\end{array}$ & & & & \\
\hline & $3 \mathrm{k}$ & Injunctions proceedings are costly & & & & \\
\hline & 31 & $\begin{array}{l}\text { There are significant differences } \\
\text { between national rules on } \\
\text { injunctions proceedings across EU } \\
\text { countries }\end{array}$ & & & & \\
\hline \multirow{5}{*}{$\begin{array}{l}\text { Satisfaction } \\
\text { with EU } \\
\text { consumer } \\
\text { policy }\end{array}$} & 1 & \multicolumn{3}{|c|}{$\begin{array}{l}\text { In your view, to what extent are the following } \mathrm{EU} \text { consumer and } \\
\text { marketing rules beneficial to consumers? }\end{array}$} & .872 & \\
\hline & 1a & $\begin{array}{l}\text { Right to be protected against } \\
\text { misleading or aggressive } \\
\text { commercial practices }\end{array}$ & \multirow{4}{*}{ Ind_v1 } & \multirow{4}{*}{$\begin{array}{l}\text { Consumer } \\
\text { benefits }\end{array}$} & & \multirow{4}{*}{.881} \\
\hline & $1 \mathrm{~b}$ & $\begin{array}{l}\text { Right to get adequate information } \\
\text { about the goods and services } \\
\text { offered, i.e. the main } \\
\text { characteristics, the total price, the } \\
\text { delivery time, etc. }\end{array}$ & & & & \\
\hline & $1 \mathrm{c}$ & $\begin{array}{l}\text { Right to get information also about } \\
\text { the unit price of goods (i.e. for one } \\
\text { kilogramme, one litre etc.) }\end{array}$ & & & & \\
\hline & $1 \mathrm{~d}$ & $\begin{array}{l}\text { Right to cancel a contract } \\
\text { concluded at a distance within } 14 \\
\text { days from the delivery goods or } \\
\text { conclusion of a service contract (the } \\
\text { 'right of withdrawal') }\end{array}$ & & & & \\
\hline
\end{tabular}




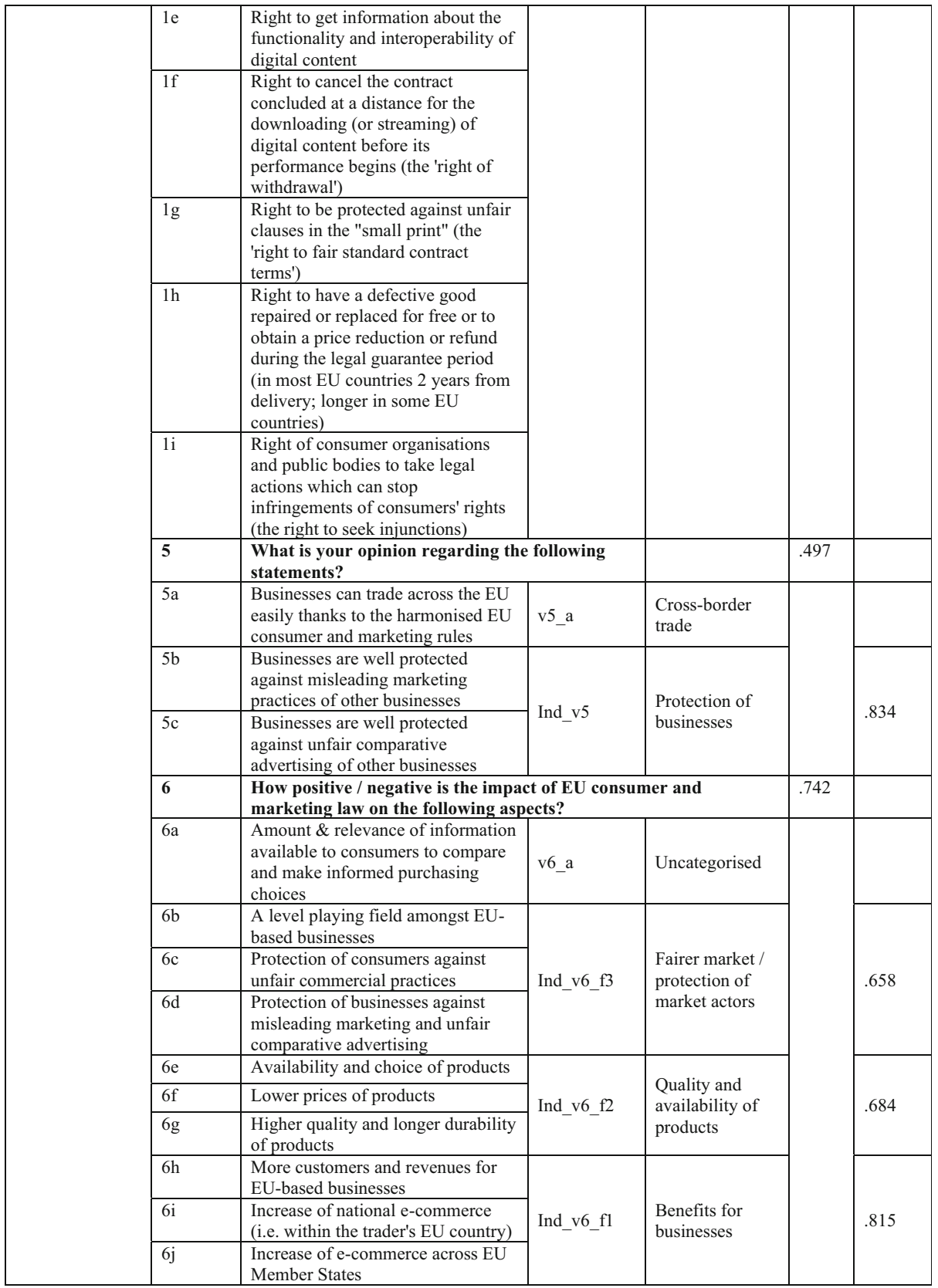




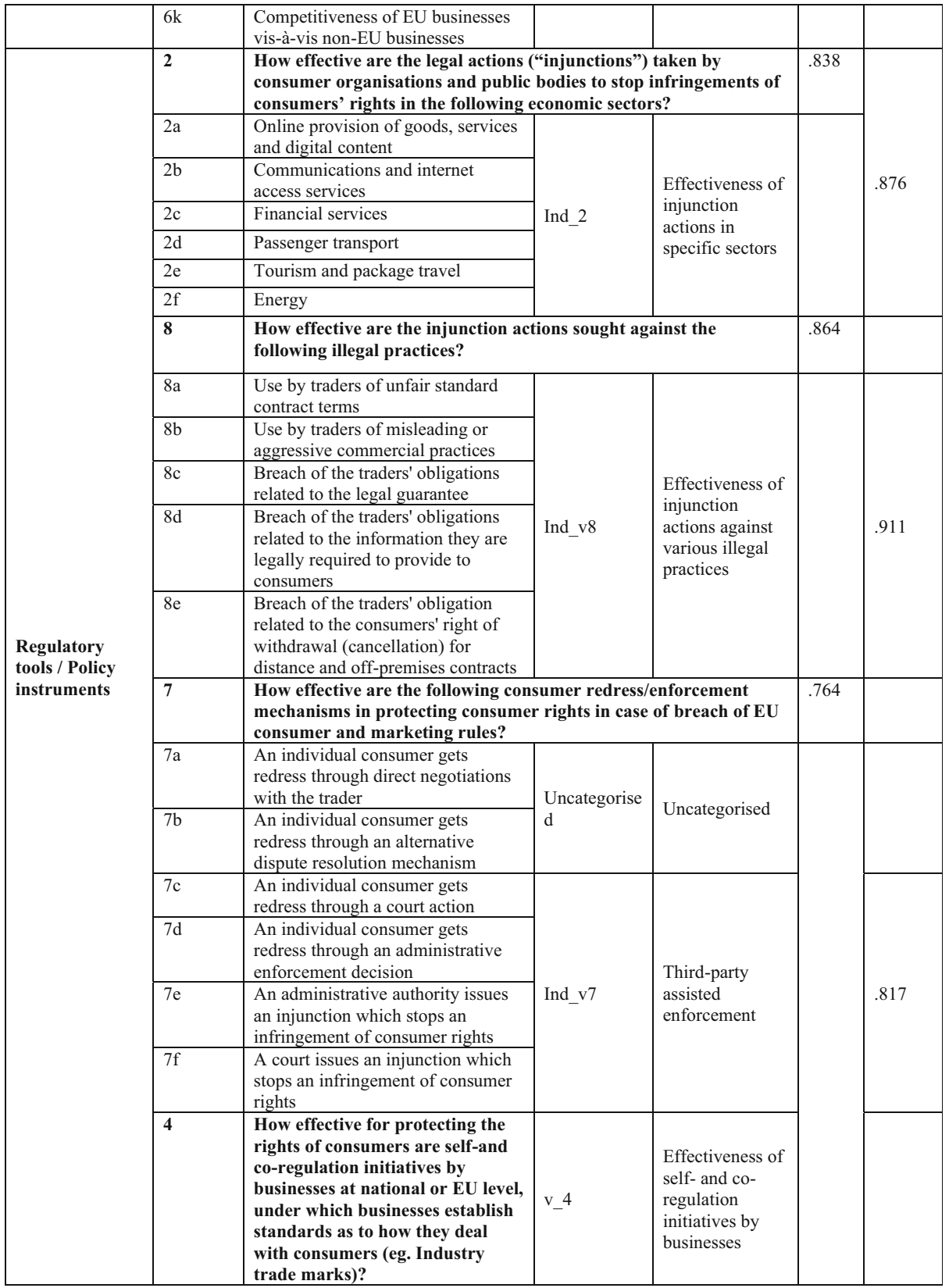




\begin{tabular}{|c|c|c|c|c|c|c|}
\hline & 15 & $\begin{array}{l}\text { How strongly do you agree or disa } \\
\text { statements about the potential are } \\
\text { marketing rules for the benefit of }\end{array}$ & $\begin{array}{l}\text { ree with each } \\
\text { to improve } \mathrm{E} \\
\text { nsumers? }\end{array}$ & $\begin{array}{l}\text { f the following } \\
\text { J consumer and }\end{array}$ & .865 & \\
\hline & $15 b$ & $\begin{array}{l}\text { The information given to } \\
\text { consumers at the advertising stage } \\
\text { should focus on the essentials } \\
\text { whilst more detailed information } \\
\text { should be required only at the } \\
\text { moment before the contract is } \\
\text { concluded }\end{array}$ & $\begin{array}{l}\text { Uncategorise } \\
\text { d }\end{array}$ & Uncategorised & & \\
\hline & $15 \mathrm{c}$ & $\begin{array}{l}\text { Online platform providers should } \\
\text { inform consumers about the criteria } \\
\text { used for ranking the information } \\
\text { presented to consumers }\end{array}$ & & & & \\
\hline & $15 \mathrm{e}$ & $\begin{array}{l}\text { The obligation to display also the } \\
\text { price per unit (eg, } 1 \mathrm{Kg}, 1 \mathrm{l} \text { ) of the } \\
\text { goods should apply to all } \\
\text { businesses irrespective of their size }\end{array}$ & & & & \\
\hline & $15 f$ & $\begin{array}{l}\text { Consumer protection against unfair } \\
\text { commercial practices should be } \\
\text { strengthened by introducing a right } \\
\text { to individual remedies, e.g. } \\
\text { compensation and/or invalidity of } \\
\text { the contract when the consumer has } \\
\text { been misled into signing a } \\
\text { disadvantageous contract }\end{array}$ & & & & \\
\hline Solutions & $15 \mathrm{~g}$ & $\begin{array}{l}\text { Consumer protection against unfair } \\
\text { contract terms should be } \\
\text { strengthened by introducing a } \\
\text { "black list" of terms that are always } \\
\text { prohibited }\end{array}$ & & & & \\
\hline & $15 \mathrm{i}$ & $\begin{array}{l}\text { Consumer protection against unfair } \\
\text { contract terms should be } \\
\text { strengthened by incorporating key } \\
\text { Court of Justice case law on the ex } \\
\text { officio duties of judges to assess the } \\
\text { presence of unfair terms }\end{array}$ & Ind_v15_f1 & $\begin{array}{l}\text { Strengthening of } \\
\text { consumer rights }\end{array}$ & & .926 \\
\hline & $15 \mathrm{j}$ & $\begin{array}{l}\text { The legal guarantee period for } \\
\text { goods should depend on their } \\
\text { characteristics (If you agree with } \\
\text { this statement please indicate the } \\
\text { relevant characteristics in the box } \\
\text { below, e.g. the category of the good } \\
\text { (such as small/large household } \\
\text { appliances, ICT products, cars etc.), } \\
\text { price, expected/ advertised lifespan) }\end{array}$ & & & & \\
\hline & $15 \mathrm{k}$ & $\begin{array}{l}\text { The period during which the defect } \\
\text { is presumed to have existed already } \\
\text { at the time of delivery of the good } \\
\text { (reversal of the burden of proof) } \\
\text { should be extended. It is } 6 \text { months } \\
\text { under current EU law but longer in } \\
\text { a few EU countries }\end{array}$ & & & & \\
\hline & 151 & $\begin{array}{l}\text { The notion of "vulnerable } \\
\text { consumers" should be reviewed/ } \\
\text { updated. Under current EU law } \\
\text { vulnerable consumers are those that } \\
\text { are particularly vulnerable to unfair } \\
\text { commercial practices because of }\end{array}$ & & & & \\
\hline
\end{tabular}




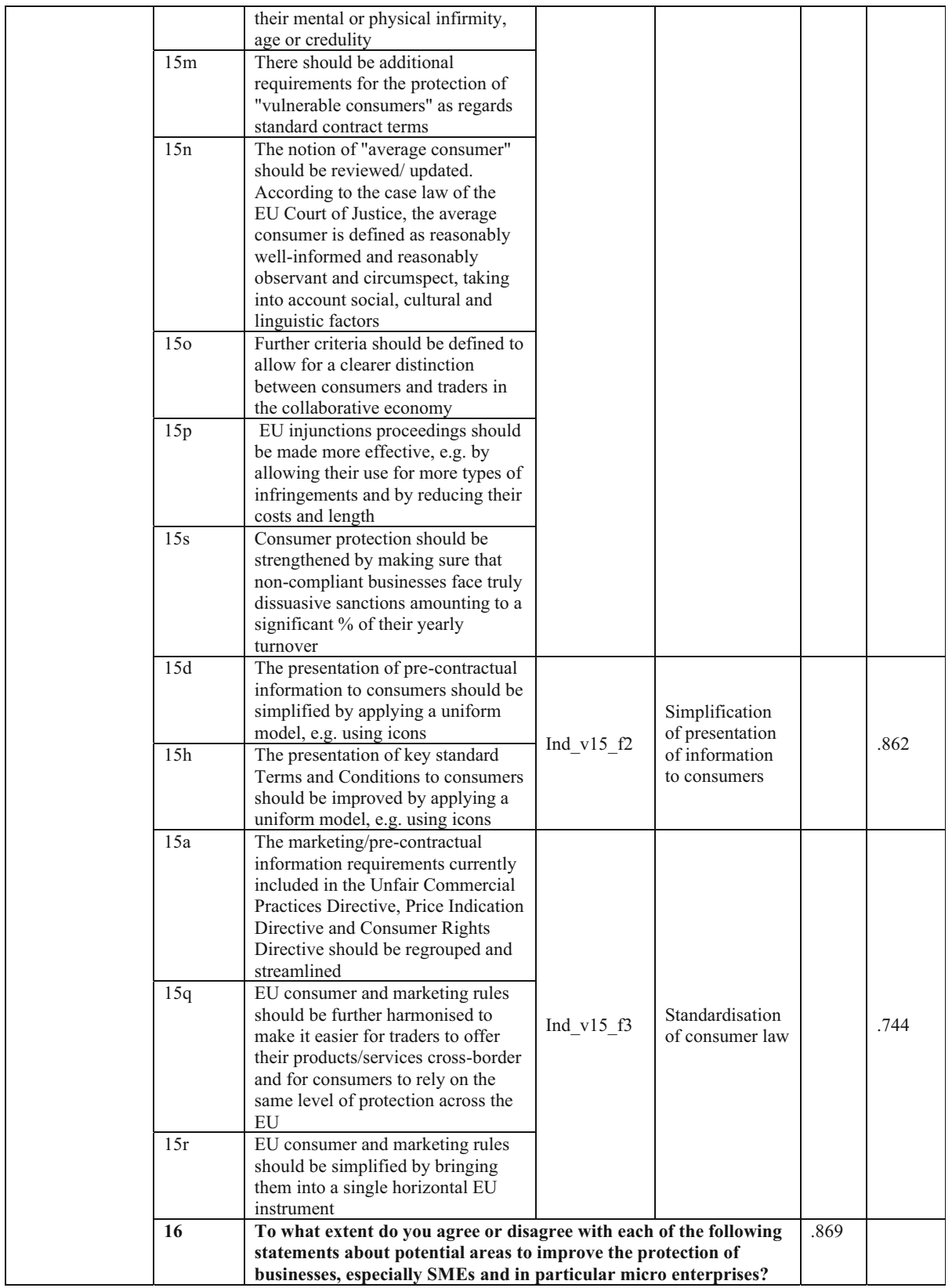




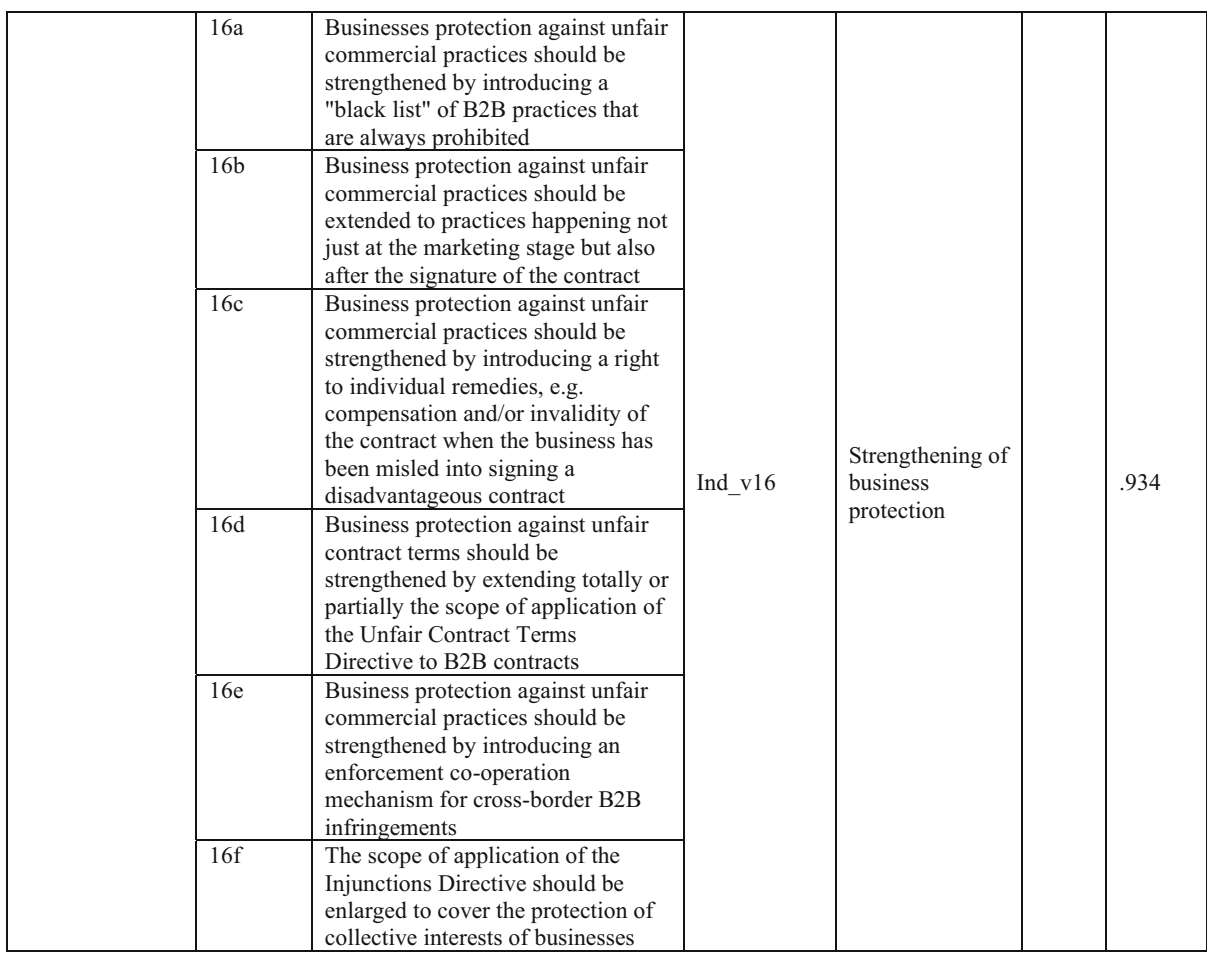

\section{Appendix B: Questions in interview guide and survey}

\section{About the informant}

- Your name (first name and surname)?

- Please fill in the name of your country and institution

\section{National situation}

- What is the role of your institution and position in national consumer policy?

- How large would you say that the consumer sector in your country is relative to the situation in other EU countries?

- Are there other differences you wish to highlight between the consumer sector in your country and the consumer sector in other EU/EEA countries?

\section{Preferences in EU consumer policy}

- What meaning/effect has EU consumer law had for (the development of) consumer policy in your country?

- In your opinion, do countries have consistent positions in European consumer policy?

- In your opinion, are there any clear (or less clear) consumer policy interest coalitions among EU countries? 
- If there are interest coalitions, are they more or less permanent, or do the country coalitions fluctuate from case to case?

- What are the main conflicts and conflict alignments in European consumer policy?

- Do you have any thoughts regarding what could explain potential differences in countries' positions in European consumer policy?

- When establishing a country position to issues in EU consumer policy, how would you describe the preliminary national negotiations on which position to take?

- For the positions expressed by the various countries in CPN, is it your impression that it matters which ministry/organization they represent?

- Are you satisfied with the harmonization level of EU consumer and marketing law?

- How do you perceive the impact of EU consumer and marketing rules regarding benefits for businesses?

- In general, do you think that the various EU redress/enforcement mechanisms are effective?

- In general, do you think that self- and co-regulation initiatives by businesses are effective?

- In general, do you think that consumer rights should be strengthened?

- Do you think EU consumer and marketing law should be (further) standardized? (e.g., through streamlining of directives, harmonization and bringing rules together in a single instrument)

- In your opinion, are there any issues you find problematic in EU consumer law/policy?

- Do you have any other information that you would like to share with us or which you might think is useful for us to know or take into account?

The original article has been corrected.

Publisher's Note Springer Nature remains neutral with regard to jurisdictional claims in published maps and institutional affiliations. 